\title{
Narratiwiteit en die Ou Testament
}

\author{
J Marais
}

Universiteit van die Oranje Vrystaat

\begin{abstract}
Narrativity in the Old Testament

The epistemological status of the narrative as a mode of communication in the Old Testament is the issue in this article. It is argued that the narrative was deliberately chosen as a means of communication because ontologically it is a mode of existence, interpretation and familiarization. In the article the fiction-versus-fact debate is broadly discussed. A textual approach, in which the semiotic value of the specific structuring of the narrative discourse is adequately acknowledged, is put forward.
\end{abstract}

\section{INLEIDING}

Die literêre benadering tot die Ou-Testamentiese narratiewe word algemeen as 'n alternatiewe paradigma in die Bybelwetenskappe aanvaar. Oor die filosofiese uitgangspunte wat hierdie nuwe paradigma ten grondslag lê, bestaan daar egter nog weinig eenstemmigheid. Heelwat probleme van filosofiese en epistemologiese aard vereis steeds aandag. Daar bestaan byvoorbeeld nog heelwat meningsverskil oor die epistemologiese aard van die narratiewe, hetsy as historiese of fiksionele narratiewe. Die vraag waarom die Ou-Testamentiese skrywer juis die narratiewe modus van kommunikasie gekies het om aan sy oortuigings gestalte te gee, bly ook nog onvolledig beantwoord. ' $n$ Verdere vraag is of hierdie Ou-Oosterse narratiewe met behulp van moderne Westerse literêre teorieë bestudeer kan word en wat die rasionaal agter sodanige bestudering behoort te wees.

Die doel van hierdie artikel is om die aard van narratiwiteit as sodanig en soos dit in die Ou-Testamentiese narratiewe voorkom vir bespreking op die tafel te plaas. Die eerste vraag wat gestel word, is waarom die Ou-Testamentiese skrywer juis die 
narratiewe modus van kommunikasie gekies het om sy boodskap te kommunikeer. 'n Tweede afdeling behels die vraag na die epistemologiese aard van die verhaal as historiese en/of fiksionele verhaal.

\section{NARRATIEWE ONTOLOGIE}

Die term narratiewe ontologie word gebruik binne 'n sekere denkrigting waar die narratief nie bloot as 'n literêre vorm gesien word nie, maar as 'n wyse van bestaan en veral as 'n wyse van interpretasie van die bestaan. Dit is 'n relatief nuwe denkrigting in die geesteswetenskappe en verdien dus aandag vir die reeds behaalde sowel as die potensiële resultate. Die narratiewe ontologie het ' $n$ wye toepassing in verskeie dissiplines wat met die Bybel gemoeid is (Hardmeier 1986:89) en is dus relevant vir die Bybelwetenskappe. Dit word onder andere in die pastoraat, onderrig en prediking gebruik.

Die mens se narratiewe vermoë word aan sy linguistiese vermoë gekoppel. Soos wat die mens 'n aangebore linguistiese vermoë het, het hy ook 'n narratiewe vermoë. Omdat hy talig dink en ervaar, is hy voordurend besig om die wêreld om hom te benoem. Hy kombineer en interpreteer so sy ervarings deur 'n narratief saam te stel uit dit wat hy ervaar het (Buttrick 1987:6-11; Schneidau 1986:133-134). Deur die narratief is hy besig om verskillende persepsies saam te groepeer en in ' $n$ verstaanbare vorm te giet. Die aktiwiteit van vertelling is dus ' $n$ wyse waarop die naïewe ervaring van individuele entiteite in die werklikheid met mekaar en met die self in verband gebring en geïnterpreteer word.

Buttrick (1987:10) maak die saak verder duidelik. Hy redeneer dat die mens deur sy linguistiese vermoë die wêreld soos hy dit leer ken, benoem. Deur 'n verhaal gee hy egter uitdrukking aan sy selfverstaan of identiteit binne daardie wêreld (Buttrick 1987:10). Die mens se bewussyn van sy eie bestaan in die werklikheid kom tot uitdrukking in die verhaal deurdat die ek van die verteller in relasie tot die werklikheid geplaas word. Op hierdie wyse maak die verteller sy verlede, met ander woorde dit wat hy tot dusver ervaar het, relevant deur dit in 'n verhaal met ander ervarings te kombineer. Hy interpreteer dit ook deur die verbande wat in die narratief tussen die verskillende elemente van die ervaring gelê word.

Schneidau (1986:136) is van mening dat die narratief die mees basiese wyse van interpretasie van die werklikheid is. Die narratiewe modus van kommunikasie is daarom ook vir alle mense verstaanbaar en betrek die leser/luisteraar oral waar dit voorkom. Elke mens het 'n natuurlike en pre-teoretiese toegang tot die wyse waarop narratiewe die werklikheid representeer. Hierdie naiewe wyse van werklikheids- 
interpretasie maak die narratief 'n uiters geskikte kommunikasiemiddel vir die kommunikasie van geloofservaring soos in die Ou Testament.

Deur ' $n$ verhaal oor die verlede te vertel, word die verlede sinvol omdat die verlede vanuit die perspektief van die hede vertel word. Op hierdie wyse word die verlede vir 'n enkeling of 'n groep deel van en relevant vir die hede gemaak (Schneidau 1977:182-184). Die individu of groep kry ook sy identiteit deur die verhaal omdat hy ná of in so 'n verhaal iemand met ' $n$ verlede is. Herion (1981) het ook gewys hoedat verskillende sosiologiese entiteite, dit wil sê sosiale strata in 'n gemeenskap, die stories oor die verlede kan manipuleer om die situasie van die hede te regverdig. Twee verskillende groepe sal dieselfde verlede op verskillende wyses hanteer omdat beide groepe se hede verskil. 'n Narratief kan dus temporeel vanuit twee ideologiese perspektiewe funksioneer. Dit kan vanuit die ideologiese perspektief van die hede op die verlede fokus of dit kan vanuit die ideologiese perspektief van die verlede op die hede fokus.

Die narratief is dus ' $n$ wyse waarop die mens homself en sy verlede verstaan. Die grootste epistemologiese belang van die narratief is waarskynlik daarin geleë dat dit kennis van die verlede familiariseer (White 1978:86). Bepaalde gebeure uit die verlede is deur Israel onthou omdat dit relevant vir die hede was. Daar is in elke gemeenskap en individu sekere sosiologiese en ideologiese tendense wat die onthou van sekere gebeure uit die verlede beïnvloed (Herion 1981:27). Dit is dus hieruit duidelik dat narratiewe en veral ook die Ou-Testamentiese narratiewe tendensieuse literatuur is. Alhoewel die Ou-Testamentiese narratiewe beslis 'n estetiese komponent het, is hulle nie in die eerste plek ter wille van die estetika geskryf nie, maar ter wille van die kommunikasie van 'n geloofservaring in die werklikheid.

Die perspektief van die outeur bepaal hoe sekere gebeure in die narratief vertel sal word. Geen gebeure is intrinsiek tragies, komies ensovoorts nie (White 1978: 20). Twee outeurs kan na dieselfde gebeure kyk en die een kan die komiese daarin sien en dit as sodanig in 'n narratief aanbied. Die ander een kan die tragiese daarin sien en dit op sodanige wyse aanbied. Dieselfde feite kan dus verskeie perspektiewe dien of benut word om verskeie perspektiewe mee te staaf. 'n Outeur konstitueer nie die werklikheid om hom nie, maar hy maak dit verstaanbaar deur dit vanuit 'n bepaalde perspektief en tema aan te bied. Dit is op hierdie punt dat die narratief weereens ' $n$ modus van interpretasie van die outeur se waarneming van die werklikheid is. Hy bepaal ' $n$ beginsel van seleksie in terme waarvan hy die historiese stof in ' $n$ narratief selekteer en struktureer. Die gebeure vertel nie hulleself nie, maar moet deur ' $n$ waarnemer vertel word (Miller 1974:461). Die verteller vertel die gebeure soos wat hy dink dit moes gebeur het, laat uit wat hy as onbelangrik beskou, 
beklemtoon die gebeure wat hy as belangrik beskou en wys die verhoudings wat hy as belangrik beskou, uit. Hy gee betekenis en inhoud aan die gebeure deur dit rondom 'n sekere perspektief te struktureer.

'n Narratief ontstaan dus omdat daar wedywerende perspektiewe bestaan. 'n Narratief moet op ten minste twee maniere vertel kan word om 'n bestaansreg te kan hè. Die verteller/outeur moet daarvan oortuig wees dat die perspektief wat hy op die gebeure het die beste of die naaste aan die waarheid is of dat dit (vir hom) sekere belangrike leemtes in die bestaande narratiewe oor die onderwerp vul. Hy kan ook oortuig wees dat sy narratief sekere probleme aan die orde stel en oplossings, wat ander bestaande narratiewe nie doen nie, uitwys. Dan eers word 'n narratief sinvol, omdat dit 'n spesifieke perspektief kan weergee (White 1978:18) en 'n bepaalde interpretasie van die werklikheid verteenwoordig.

Omdat die historiese narratief die perspektief van ' $n$ verteller of outeur weergee, is dit reeds ' $n$ interpretasie (Schneidau 1977:177). Nuwe feite word in die ou patrone van die geskiedenis gegiet en geinterpreteer (Waldman 1980:9) of ou patrone word vanuit nuwe feite en perspektiewe herinterpreteer. Die feite staan dus in diens van die interpretasie en die perspektief. Daar moet ook in gedagte gehou word dat elke narratief ' $n$ abstraksie is aangesien geen perspektief en interpretasie volledig is nie (White 1978:90). Dit is slegs 'n aanbieding of interpretasie vanuit een perspektief. Elke narratief is dus altyd 'my narratief', met ander woorde, die storie soos deur een spesifieke persoon gesien.

'n Verdere funksie van die narratief is dat die werklikheid en die ideale deur 'n vertelling oor die verlede met mekaar in verband gebring word (Kort 1988:10). Volgens Kort (1988:10) verskaf die narratief 'n onderliggende eenheid aan die menslike ervaring. Dit bind die werklikheid en ervaring saam nog voor dit deur analitiese denke geskei word.

Die narratief vervul 'n belangrike funksie deurdat dit die verskille tussen kulture oorbrug (Kort 1988:8). In bepaalde gevalle waar die linguistiese verskille die kommunikasie tussen kulture bemoeilik, oorbrug narratiewe juis hierdie verskille omdat dit ' $n$ meer basiese semiotiese aktiwiteit is wat deur mense van alle kulture geinterpreteer kan word. Daar is uiteraard ook beperkings op die kommunikasievermoë van narratiewe, maar Propp (1975) het reeds duidelik aangetoon in watter mate die narratief ' $n$ semiotiese struktuur is wat die beperkings van taal te bowe gaan.

Die narratief is ontologies belangrik deurdat dit die mens se bestaan in die tyd verreken. Die narratief is 'n 'tyd-ding' ('time-thing' volgens Scholes 1981:205). Dit vertel van die mens se bestaan in die tyd (Comstock 1986:121). Deurdat dit 'n patroon aan die tyd gee, gee dit sin aan die lewe en verdryf die vrees vir die dood 
(Rüsen 1987:2). Elke mens het ook 'n besef van narratiwiteit omdat elke mens in die lewe rondom hom die basiese temporele aspekte, naamlik 'n begin, middel en einde, van 'n narratief raaksien (Buttrick 1987:11-13).

Die stelling kan dus hier gemaak word dat die narratief in sy ontologiese sin beslis in die Ou Testament benut word. Die narratief gee uiting aan die Ou-Testamentiese skrywer se verstaan van die geskiedenis. Schneidau (1977:1-49) en andere het aangetoon hoedat die Ou-Testamentiese samelewing en ideologie/kosmologie wat die Ou-Testamentiese narratiewe ten grondslag lê, van mitologiese samelewings verskil. Die belangrikste verskil is daarin geleê dat daar in die Ou-Testamentiese narratiewe met 'n lineêre geskiedsiening en monoteïsme in kontras met die sikliese geskiedsiening en politeisme van die mitologiese samelewings gewerk word. God staan bo en buite die kultuur en die natuur en kan in beide die kultuur en die natuur ingryp. Die narratief is 'n uiters geskikte draer om aan hierdie ideologiese onderskeid uitdrukking te gee. Alhoewel daar meningsverskille tussen geleerdes bestaan oor die aard en omvang van die verskille tussen genoemde twee ideologieë, maak selfs 'n kritikus van hierdie godsdienshistoriese onderskeidings soos Sternberg (1987:87-89) dit duidelik hoedat die narratief sekere ideologiese aspekte van die Ou-Testamentiese kosmologie dramatiseer. Die narratief as teks veronderstel 'n lineêre geskiedenis op die vlak van die gerefereerde werklikheid. Dit laat ruimte vir God se betrokkenheid in die geskiedenis en vir ontwikkeling in die geskiedenis. Dit staan in skerp kontras met die sikliese geskiedsiening van die mitologiese kulture waar alle gebeure van 'n herhalende aard is. Die narratief is ook uitmuntend daarvoor geskik om die epistemologiese onderskeid tussen God en die mens te dramatiseer (Sternberg 1987:129-158, vergelyk ook Marais (1989) vir 'n bespreking van fokalisasiestrategieë in die Ou-Testamentiese narratiewe).

Elkeen van die aspekte wat hierbo genoem is, sou verder uitgewerk kon word ten opsigte van hulle toepassing in die Ou-Testamentiese narratiewe. So 'n volledige bespreking val egter buite die doelstelling en omvang van hierdie artikel. Dit kan hier bloot gestel word dat die Ou-Testamentiese narratiewe die interpretasiemodus, die voorwetenskaplike kommunikasie-modus, die identifikasie-modus van die ervaring van die Ou-Testamentiese mens is. Die Ou-Testamentiese narratiewe 'dra' dus ten opsigte van 'n verskeidenheid ontologiese aspekte die ideologie/teologie van die Ou Testament.

\section{HISTORIESE FIKSIONALTETT IN DIE OU TESTAMENT}

Die veelvoudige voorkoms van verhalende literatuur in die Ou Testament is ' $n$ feit wat nie ontken kan word nie. Inteendeel, die hele Bybel is uiterlik in 'n narratiewe 
vorm gegiet met 'n begin, middel einde (Kort 1988:2). Die epistemologiese aard en waarde van die narratiewe is egter nog geen uitgemaakte saak nie. Dit is belangrik om die epistemologiese aard van die narratiewe in die Ou Testament te bepaal omdat dit uiteindellik die wyse van bestudering van die narratiewe bepaal. Indien die literêre aard van die Ou-Testamentiese narratiewe beredeneer kan word, sal dit verskeie implikasies hê, onder andere vir die epistemologie. Die bespreking in hierdie afdeling het dus as probleemstelling die vraag of daar inherente literêre eienskappe in die Ou-Testamentiese narratiewe is wat die leser dwing om (ook) literêr met die narratiewe om te gaan en of dit 'n kwessie van voorkeur vir die leser is of hy die narratiewe op 'n literère wyse wil lees of nie.

Die probleem soos hierbo gestel, kan op verskeie wyses beredeneer word. Die eerste moontlikheid is om op deduktiewe wyse aan te dui dat daar wel literêre strategieè in die Ou-Testamentiese narratiewe voorkom en dat die narratiewe dus self daarop aanspraak maak om literêr bestudeer te word. 'n Voorbeeld hiervan is die studie van Marais (1989) waarin aangetoon is dat fokalisasie as literêre strategie wel in die Ou-Testamentiese narratiewe benut word.

Die tweede wyse van beredenering behels dat daar induktief bewyse aangevoer word dat die narratiewe bedoel is om literêr gelees te word. Dit behels onder meer historiese rekonstruksies wat outeursintensie, literêre geskiedenis en die vergelyking met ander literatuur uit dieselfde tydvak insluit. In hierdie afdeling sal kortliks aan die tweede wyse van beredenering aandag gegee word. Dit is belangrik om daarop te let dat elkeen van hierdie benaderings 'n eie filosofiese onderbou het wat verreken moet word, maar nie in hierdie artikel in detail hanteer kan word nie.

Verskeie geleerdes het reeds die tipe narratief wat in die Ou Testament voorkom as historiese of gehistoriseerde fiksie (historicized fiction) beskryf (Scheidau 1977:215, Sternberg 1987:24, 29, 34-35). So 'n aanduiding impliseer dat die verhale fiktief is met 'n historiese kern en 'n mindere of meerdere mate van historiese verwysing. Alter (1981:25) is van mening dat dit meer korrek sou wees om in die meeste gevalle van fiksionele of gefiksionaliseerde geskiedenis (fictionalized history) te praat. In hierdie artikel word voorkeur aan die standpunt van Alter verleen omdat dit reg laat geskied aan sowel die historiese karakter van die Ou-Testamentiese narratiewe as aan die kreatiewe, literêre verwerking van sodanige geskiedenis. Sowel Schneidau (1977:1-49, 215) as Sternberg (1987:30-35) aanvaar ook dat die Ou-Testamentiese narratiewe histories is, met ander woorde, die narratiewe verwys na werklike historiese gebeure of ervaring. Daar kan dus in aansluiting by hierdie geleerdes aanvaar word dat die Ou-Testamentiese narratiewe historiese narratiewe is. 
Die vraag ontstaan of al die narratiewe ewe histories of fiksioneel is en of ' $n$ funksionele onderskeid tussen die verskillende tipes narratiewe getref kan/moet word. Die mate waarin sommige van hierdie historiese narratiewe 'gefiksionaliseer' is, is die onderwerp wat verder in hierdie afdeling bespreek sal word. Waterdigte skeidings of onderskeidings ten opsigte van hierdie probleem is egter nie haalbaar nie.

Daar kan in hooftrekke drie 'tipes' Ou-Testamentiese narratiewe onderskei word. Die eerste is 'n volledig fiksionele narratief waarvan die verhaal van Rut 'n moontlike voorbeeld kan wees. ' $n$ Ander soort is 'n volledig historiese narratief. Die laaste moontlikheid behels 'n mengsel van die twee. Die probleem wat egter ontstaan, is dat daar verskillende kriteria aangelê word in terme waarvan 'n verhaal as fiksioneel, histories of 'n mengsel van die twee geidentifiseer kan word. In die meeste verhale het dit onmoontlik geword om die akkuraatheid van historiese verwysings (volledig) te bepaal. Die werklike gebeure is so verwerk rondom perspektiewe en temas dat dit onmoontlik geword het om die werklike gebeure uit die tekstuele gegewens te rekonstrueer (Frye 1982:40). Die verskille tussen eksponente van die verskillende historiese benaderings getuig van hierdie probleem. Die probleem sou met 'n fundamentalistiese stelling, dat alles wat in die Bybel staan net so gebeur het, van die tafel gevee kan word. In so 'n geval word 'n beroep op 'n onkritiese geloof gedoen om die probleem op te los. Daar is egter ' $n$ ander (meer vrugbare) wyse waarop hierdie probleem hanteer kan word. Dit is ' $n$ tekstuele benadering, soos deur Kort (1988) voorgestel, waar die skeiding tussen feit en fiksie of gebeure en teks kleiner word, maar waar die tekstuele verwysings wel deeglik verreken word.

'n Groot probleem rondom die onderskeiding tussen geskiedenis en fiksie het ontstaan deurdat die onderskeiding 'n volwaardige epistemologiese skeiding in die historiografie geword het. Sternberg (1987:25) stel dit duidelik dat die geskiedenis nie 'n stel feite is nie, maar 'n diskoers wat aanspraak daarop maak dat dit 'n weergawe van werklike gebeure is. Net so is fiksie nie onwaar nie, maar 'n diskoers wat aanspraak mak op vrye skepping (invention). 'n Fiksie-skrywer word van 'n geskiedskrywer onderskei, nie omdat hy feite vermy nie, maar omdat hy onafhanklik van feitelikhede is. Beide gebruik feite, die een is net op 'n ander manier daaraan gebonde as die ander, of glad nie daaraan gebonde nie (Sternberg 1987:29).

Die implikasie hiervan is dus, soos $\mathrm{Nel}$ (1989:7-8) tereg aandui, dat die historiese vraag in die bestudering van sodanige tekste van sekondêre belang is. Die vraag na die betekenisopbou van die teks soos die tekstuele gegewens dit kommunikeer, verkry die primaat. Tekste, hetsy histories of fiksioneel, word in terme van hulle waarheidsaanspraak gelees. Hierdie waarheidsaansprake staan baie selde, indien ooit, in 'n een-tot-een-relasie met die 'waarhede' wat die storie konstitueer. 
Aangesien hierbo reeds vermeld is dat die Ou-Testamentiese narratiewe tendensieuse literatuur is, sal sowel die literêre aard as die tendens (geloofskommunikasie) in die bepaling van die waarheidsaansprake en in die bestudering van die teks verreken moet word.

Die feit dat die diskoers van die Ou-Testamentiese narratiewe literêr is, impliseer nie dat dit nie histories is nie (Sternberg 1987:30-31). Die Ou-Testamentiese narratiewe maak self daarop aanspraak dat dit histories is (Sternberg 1987:31). Onder die beskerming van ideologie/teologie is die geskiedenis kreatief verwerk sodat die verskil tussen feit en fiksie in sommige gevalle glad nie meer duidelik onderskeibaar is nie (Sternberg 1987:34).

Vir die doel van hierdie artikel word saam met Kort (1988:11) aanvaar dat fiksionele en historiese narratiewe twee verskillende aktualiserings van alternatiewe moontlikhede binne die narratiewe vorm is. In literêre terme gestel, kom dit daarop neer dat die narratiewe van die Ou Testament, wat die fabula betref, meestal aan historiese feite gekoppel is. Dit is dus onmoontlik om die akkuraatheid van sommige verwysings in sommige narratiewe volgens historiese beginsels na te vors. Wat die sjuzet betref, word egter in 'n groot aantal van hierdie verhale literêre strategieë benut wat literêr bestudeer behoort te word. In die literêre bestudering van die OuTestamentiese narratiewe word die intensie van die diskoers dus verreken. Hierdie intensie is in sommige van die narratiewe dié van die fiksionele, literêre kommunikasie van die teologiese inhoud. Die vertellinig is dus ' $n$ wyse van kommunikasie oor die werklikheid. Die onderskeidende aard van hierdie kommunikasie lê in die onderskeidende strukturering van die kommunikasie en nie in die entiteite of feite van die storie nie.

Die term 'historiese fiksie' wil dus geensins afbreek doen aan die historiese karakter van die Ou-Testamentiese narratiewe nie. Dit wil juis, in teenstelling met 'n term soos 'mite', erken dat die Ou-Testamentiese narratiewe wel histories is of 'n historiese kern kan hê. Dit wil egter ook aandui dat die Ou-Testamentiese narratiewe nie geskiedskrywing in die moderne, Westerse sin van die woord is nie. Dit is verwerkings van die geskiedenis wat sekere estetiese verwerkings met die doel om 'n boodskap effektief te kommunikeer, insluit (Sternberg 1987:1-3). Die feit dat die Ou-Testamentiese narratiewe (ook) esteties van aard is en dus literêr bestudeer behoort te word, kan dus as uitgangspunt geneem word. Die presiese estetiese aard en waarde van die narratiewe, die literêre konvensies waarvolgens gekommunikeer word en verskeie ander literêre vrae moet egter nog uitgeklaar word.

Daar kan nou kortliks gekyk word na die resultate van studies wat narratiewe kommunikasie in die Ou-Testamentiese narratiewe as uitgangspunt het. Hierdie bespreking pretendeer nie om volledig te wees nie. 
Dit is veral Schneidau (1977) en Alter (1981:25-26), op voetspoor van Schneidau, wat aangetoon het hoedat die Ou-Testamentiese narratiewe met die kosmologie van die Ou Ooste in spanning staan. In teenstelling met die 'geslote' siening van die geskiedenis in die mitiese samelewing is daar ' $n$ 'oop' siening van die geskiedenis in die Ou-Testamentiese narratiewe (Jobling 1983:90). Die Ou-Testamentiese narratiewe verteenwoordig dus 'n radikale breuk met die heidense, mitiese kosmologieë. Schneidau (1977) toon ook aan in watter mate die Ou-Testamentiese narratiewe 'n kritiek op die mitologiese denke is.

Vanuit 'n kultuurhistoriese perspektief het Schneidau (1977) aangetoon hoedat daar in die Ou-Testamentiese narratiewe wegbeweeg word van die sikliese (geslote) kosmologie van die samelewings van die Ou Ooste. Volgens hierdie denkstruktuur is die geskiedenis bloot ' $n$ herhaling van vasgestelde patrone. Ook die mens is ' $n$ slagoffer van hierdie sikliese herhaling.

In die Ou-Testamentiese narratiewe hoef alles nie meer in die voorafbepaalde mitologiese struktuur in te pas nie, want God is transendentaal en handel volgens vrye keuse in die geskiedenis (Schneidau 1977:3; vergelyk die res van die boek vir'n volledige bespreking). In die Ou Testament word met 'n lineère siening van die geskiedenis gewerk. Veranderlikheid, teenstrydighede en al die paradokse van die menslike bestaan kan nou deur middel van narratiewe gekommunikeer word (Schneidau 1977:146-147). Die kosmologie is nie meer geslote soos in die mitologiese samelewings nie. Dit is oop vir God se ingrype, vir onverklaarbaarhede, vir karaktergroei, ensovoorts.

Frye (1982:9) werk meer vanuit 'n literêre benadering en met universele, mitologiese denkstrukture van die korporatiewe bewussyn van die mensdom. Hy noem die mitologiese denke 'metaforiese' denke. Hierdie denke aanvaar 'n eenheid tussen God(e) en die natuur en funksioneer op grond van 'n geslote paradigma waarin elke mens en gebeure bloot binne die paradigma ingepas word. Daar is dus nooit ruimte vir verandering en vernuwing nie.

Hierteenoor identifiseer Frye (1982:9-10) 'n metonimiese denkstruktuur by die Ou-Testamentiese skrywers. Dit stem ooreen met wat Scheidau geïdentifiseer het, maar maak verder duidelik dat die metonimiese denkstruktuur ook op die literatuur ' $n$ invloed het. Ook in die literatuur het die skrywer van die Ou Testament, anders as in 'n mitologiese samelewing. die vryheid om met moontlikhede en selfs onmoontlikhede te eksperimenteer, karaktergroei toe te laat, 'n spanningslyn in die geskiedenis te sien, ensovoorts. Volgens Frye (1982:10) lei metonimiese denke tot 'n moraliserende en rasionaliserende benadering. Die ontwikkeling van magiese denke tot poëtiese denke impliseer artistieke vryheid (Frye 1982:25). Hieruit kan afgelei word dat die Ou-Testamentiese skrywers, binne die raamwerk van historiese 
en teologiese beperkings wat deur die samelewing en hulle geloof op hulle gelê is, artisties kreatief was in die opskrifstelling van die verhale. Hulle het geput uit die beskikbare estetiese en menslik verstaanbare bronne wat tot hulle beskikking was ten einde die geloofsboodskap, wat hulle oortuiging was, te kommunikeer.

Alter $(1981: 15-22,157)$ maak 'n sterk saak daarvoor uit dat die estetiese vorm in die Ou-Testamentiese narratiewe die religieuse inhoud dra en dit ten volle tot sy reg laat kom. Alter (1981:60) is van mening dat die uniekheid van die Israelitiese geloof hulle skrywers tot die hoë estetiese vormgewing van hulle godsdiens gedryf het. Whybray (1983:83) wys egter daarop dat Von Rad (1984:166-224) beweer het dat die literêre strategieë wat in die Ou-Testamentiese narratiewe benut word self 'n historiese ontwikkeling deurgemaak het. Alhoewel Whybray (1983:83) toegee dat die unieke geloof van Israel wel 'n rol te speel gehad het in die literêre prestasies van Ou-Israel, meen hy tog dat Von Rad se standpunt oorweging verdien.

In sy studie werk Alter (1981) glad nie a-histories nie. Hy erken die feit dat nie alle probleme in die Ou-Testamentiese narratiewe deur literêı strategieë verklaarbaar is nie. Tog gaan hy van die standpunt uit dat die historiese kritiek eers toegepas moet word wanneer dit onmoontlik blyk om 'n sinvolle literêre verklaring vir 'n teks aan te bied. Hierdeur illustreer hy 'n belangrike beginsel van die literêre benadering, naamlik dat die wantrouestandpunt ten opsigte van 'n teks verwerp word. Dit impliseer dat die leser as uitgangspunt aanvaar dat 'n bepaalde teks 'n sinvolle semiotiese geheel vorm en dat die leesakt tot betekenisontginning lei. Dit lyk na 'n vrugbaarder benadering as die histories-kritiese paradigma waar die toestand, ontstaan en samehang van 'n teks by voorbaat bevraagteken word.

Alter (1981:47-63) se siening van literêre konvensies soos die 'type scene' dui op die feit dat hy elke literêre teks wel teen 'n historiese agtergrond lees. Dit is onmoontlik om 'n teks volledig a-histories te lees, aangesien die ekstra-tekstuele verwysings in 'n teks die (historiese) kennis van 'n leser aktiveer en daaruit betekenis genereer. Op hierdie manier kan Alter die geloofsdoel waarmee die Ou-Testamentiese narratiewe geskryf is met 'n literêre benadering versoen. Volgens hom is die Ou-Testamentiese narratiewe primêr met 'n geloofsdoel geskryf, alhoewel dit nie uitsluitlik met daardie doel geskryf is nie. Die outeurs het ook met fiksionele aspekte soos karakterisering, dubbelsinnigheid en ironie geëksperimenteer (Alter 1981:46). Daar is ook by geleentheid met die oog daarop geskryf dat die leser die teks moet genier.

Kort (1988:97-133) sluit op 'n baie belangrike wyse by Alter se konsep van literêre konvensies aan met sy bespreking van die intertekstualiteit van die Bybelse teks. Sy standpunt is dat daar in die Ou Testament sekere tipiese tekstuele eienskappe soos herhaalbaarheid en stabiliteit voorkom (Kort 1988:106). Hierdie uni- 
versele aspekte word gebalanseer deur die partikulariteit in elke teks. In die OuTestamentiese narratiewe is daar dus voortdurend 'n balans tussen teks en interteks (Kort 1988:106-109). Die interteks is in hierdie geval die literêre konvensie of geskiedenis wat as agtergrond dien vir die konvensies van die huidige teks. In die OuTestamentiese narratiewe is die amp van rigter byvoorbeeld as interteks baie belangrik. Hierte enoor is die individualiteit wat aan elke rigter gegee word van net soveel belang (Kort 1988:107). Kort (1988:108) dui ook aan hoedat die Bybelse teks 'n interteks vir moderne literatuur is. Frye (onder andere 1982:xi-xiii) het ook reeds aangedui in watter mate die Bybelse teks onmisbaar is in die verstaan van moderne literatuur.

\section{SAMEVATTING}

Die vraag wat in die literêre benadering aan die teks gestel word, is dus een van betekenisskepping soos deur die semiotiese struktuur in die teks gegenereer. Die literêre strategieë vorm deel van hierdie betekenisdraende semiotiese struktuur. Dit het die belangrike metodologiese implikasie dat die Ou-Testamentiese narratiewe, wat op 'n literêre wyse kommunikeer, op 'n literêre wyse bestudeer moet word.

Daar is vanuit verskeie oorde en onder mekaar kritiek gelewer teen verskeie aspekte van die teorieë wat in die vorige afdeling aan die orde gestel is. Dit is onmoontlik om binne die bestek van 'n artikel soos hierdie op die detail van die kritiek ingegaan. Wat egter duidelik uit die voorafgaande bespreking blyk, is dat daar op twee kardinale punte onduidelikheid binne die narratiewe paradigma is.

In die eerste plek is daar onduidelikheid oor die epistemologiese status van die narratiewe en van die hele paradigma as sodanig. Die debat oor die historisiteit/fiksionaliteit en waarheid/betekenis het juis die epistemologiese status van die narratief as problematiek in die oog. Die semiotiese aard van representasie moet in hierdie problematiek teoreties verreken word. Die wyse waarop betekenis deur'n teks gegenereer word, die rol wat die outeur daarin speel, die rol wat die teks daarin speel en die rol wat die leser daarin speel, is van kardinale belang. Daar sal ook opnuut gekyk moet word na filosofiese vooronderstellings oor hierdie aspekte wat subtiel 'n rol speel. Duidelikheid oor die werklikheidsmodel wat aan 'n leser se resepsie ten grondslag lê, is ook noodsaaklik omdat dit deur hom op die teks geprojekteer word.

Die tweede probleem, wat hiermee nou saamhang, is die rasionaal agter die bestudering van die Ou-Testamentiese narratiewe met behulp van moderne literêre teorieè. Hierdie probleem roep die probleem van konvensionaliteit en intertekstua- 
liteit ten opsigte van die Ou-Testamentiese narratiewe op. Daarmee saam hang weer in die vorm van 'n sirkelredenasie die vraag na die historiese rekonstrueerbaarheid van bepaalde konvensies en die daarmee gepaardgaande plasing van die sentrum van betekenisskepping, hetsy in die outeur of teks of leser.

Met die potensiaal van die narratiewe paradigma in die oog, is dit dus nodig om die filosofiese en metodologiese vooronderstellings wat hierdie paradigma ten grondslag lè, verder uit te klaar.

\section{Literatuurverwysings}

Alter, R 1981. The art of biblical narrative. London: George Allen \& Unwin.

.-- 1983. A response to critics. JSOT 27, 113-117.

Alter, R \& Kermode, F (eds) 1987. The literary guide to the Bible. Cambridge: Harvard University Press.

Bar-Efrat, S 1989. Narrative art in the Bible. Sheffield: The Almond Press.

Barr, J 1976. Story and history in biblical theology. Journal of Religion 56, 1-17.

Berlin, A 1983. Poetics and interpretation of biblical narrative. Sheffield: The Almond Press.

Buttrick, D 1987. Homiletic: Moves and structures. Philadelphia: Fortress Press.

Carr, D 1986. Narrative and the real world: An argument for continuity. Histony and Theory 25(2), 117-131.

Comstock, G 1986. Truth or meaning: Ricoeur vs Frei on biblical narrative. Journal of Religion 66, 117-140.

Frye, N 1982. The great code. London: Routledge \& Kegan Paul.

Gaston, P L 1987. Text and textbook: The Bible as literature. Papers on Language and Literature 23, 104-111.

Gross Louis, K R R (ed) 1974. Literary interpretations of Biblical narratives, Vol 1. Nashville: Abingdon Press.

-.- (ed) 1982. Literary interpretations of biblical narrative, Vol 2. Nashville: Abingdon Press.

Habel, N C 1983. The narrative art of Job: Applying the principles of Robert Alter. JSOT 27, 101-111.

Hammond, G 1983a. The Bible and literary criticism, part 1. Critical Quarterly 25(2), 5-20.

-.. 1983b. The Bible and literary criticism, part 2. Critical Quarterly 25(3), 3-15.

Hardmeier, C 1986. Old Testament exegesis and linguistic narrative research. Poetics 15, 89-109. 
Herion, $G$ A 1981. The role of historical narrative in biblical thought: The tendencies underlying Old Testament historiography. JSOT 21, 25-57.

Jobling, D 1983. Robert Alter's the art of biblical narrative. JSOT 27, 87-99.

Kort, W A 1988. Story, text and Scripture. London: The Pennsylvania State University Press.

Licht, J 1978. Stonytelling in the Bible. Jerusalem: The Magnes Press.

Lindbeck, G 1980. The Bible as realistic narrative. Joumal of Ecumenical Studies 17, 81-85.

Marais, J 1989. Vokalisasie in Ou-Testamentiese narratiewe: 'n Narratologiese ondersoek. M A-verhandeling, UOVS.

McKnight, E V 1985. The Bible and the reader. Philadelphia: Fortress Press.

Miller, J H 1974. Narrative and history. English Literary history 41, 455-473.

Nel, P J 1988. Jona en ' $n$ nuwe paradigma. Ongepubliseerde professorale intreerede. Universiteit van die Oranje-Vrystaat.

Propp, V 1975. The morphology of the folk tale. London: University of Texas Press.

Rüsen, J 1987. Historical narration: Foundations, types, reason. History and Theory. $26(4), 87-97$.

Schneidau, H N 1977. Sacred discontent: The Bible and the Westem tradition. Baton Roudge: Lousiana State University Press.

... 1986. Biblical narrative and modern conciousness, in McConnell, F (ed), The Bible and the narrative tradition. Oxford: University Press.

Scholes, $R$ 1981. Language, narrative and anti-narrative, in Mitchell, W J T (ed), On narrative, 200-208. Chicago: University of Chicago Press.

Sternberg, M 1987. Poetics of biblical narrative. Bloomington: Indiana University Press.

Von Rad, G 1984. The problem of the hexateug and other essays. London: SCM Press.

Waldman, M R 1980. Toward a theory of historical narrative: $A$ case study in PersoIslamitic historiography. Ohio: Columbus.

Warnick, B 1987. The narrative paradigm: Another story. Quarterly Joumal of Speech 73(2), 172-182.

White, H 1978. The tropics of discourse. London: John Hopkins University Press.

Whybray, R N 1983. On Robert Alter's 'The art of Biblical narrative'. JSOT 27, 7586.

Wilder, A N 1985. Story and story-world. Interpretation 37, 353-364. 